\title{
Anestesi untuk Pasien dengan Sindrom Meigs
}

\author{
Dewi Yulianti Bisri \\ Departemen Anestesiologi \& Terapi Intensif Fakultas Kedokteran Universitas Padjadjaran-RSUP Dr. Hasan \\ Sadikin Bandung
}

\begin{abstract}
Abstrak
Sindrom Meigs khas dengan adanya tumor ovarium jinak yang berhubungan dengan ascites dan hidrotoraks sisi kanan. Ini kasus yang jarang dan patofisiologinya belum jelas. Diagnosis banding dengan neoplasma ovarium harus didiskusikan sebelum dilakukan tindakan pembedahan. Efusi pleura dan ascites akan hilang secara spontan dan permanen setelah pengangkatan tumor. Anestesi untuk sindroma ini merupakan tantangan yang nyata. Masalah metabolik hemodinamik, respirasi dan hipertensi abdominal merupakan risiko anestesi utama. Pengelolaan risiko-risiko ini merupakan prioritas perioperatif. Kasus: Wanita usia 23 tahun, Tinggi Badan/Berat Badan: 156 $\mathrm{cm} / 70 \mathrm{Kg}$, datang dengan keluhan perut yang semakin membesar sejak 6 bulan sebelum masuk rumah sakit, pemeriksaan fisik dan penunjang menunjukkan adanya ascites, efusi pleura, anemia dan malnutrisi. Dilakukan operasi pengangkatan tumor dengan anestesi umum. Induksi anestesi dengan posisi setengah duduk, preoksigenasi dengan oksigen 100\%, induksi dilakukan dengan pemberian fentanyl 100 mcg perlahan. Propofol diberikan 100 mg diberikan secara titrasi, atracurium $25 \mathrm{mg}$ dilakukan laringoskopi direk, pemasangan ETT no 7.0. Rumatan anestesi dengan isoflurane $1,2 \mathrm{vol} \%, \mathrm{O}_{2}$ : $\mathrm{Air}=\mathrm{FiO}_{2}$ 50\%. Setting ventilator VCV f $12 \mathrm{Vt} 450 \mathrm{PEEP} 5 \mathrm{FiO} 250 \%$. Pasien diposisikan supine. Sebagai simpulan: Sindrom Meigs adalah penyakit jinak, jika diterapi dengan benar, tidak ada kekambuhan setelah operasi pengangkatan massa. Risiko pernafasan dan hemodinamik merupakan masalah anestesi utama.
\end{abstract}

Kata kunci: anestesia, ascites, sindrom Meigs, tumor ovarium

\section{Anesthesia for Patient with Meig's Syndrome}

\begin{abstract}
Meigs syndrome is characterized by the presence of a benign ovarian tumor associated with ascites and a right-sided hydrothorax. This is a rare seen and the pathophysiology is unclear. Differential diagnosis with ovarian neoplasia should be discussed before surgery. Pleural effusion and ascites will resolve spontaneously and permanently after removal of the tumor. Anesthesia for this syndrome is a real challenge. Respiratory, hemodynamic and metabolic problems and abdominal hypertension are major anesthetic risks. Management of these risks is a operative priority. Case: A 23 year old oman, came with complain of an enlarged stomach since 6 months before admission to the hospital, body height/body weight: $156 \mathrm{~cm} / 70 \mathrm{Kg}$, physical examination and investigations showed the presence of ascites, pleural effusion, anemia and malnutrition. Surgical removal was performed under general anesthesia. Anesthesia induction was performed in a semi-sitting position with $100 \%$ oxygen as preoxygenation and slowly administering $100 \mathrm{mcg}$ fentanyl. Propofol is given $100 \mathrm{mg}$ by titration, atracurium $25 \mathrm{mg}$ to perform direct laryngoscopy, and then insertion of ETT no 7.0. Anesthsia maintenance with isoflurane 1,2 vol \%, $\mathrm{O}_{2}:$ air $=\mathrm{FiO}_{2}$ $50 \%$. Ventilator setting VCV f $12 \mathrm{Vt} 450$ PEEP $5 \mathrm{FiO}_{2} 50 \%$. The patients is positioned supine. In conclusion: Meigs syndrome is benign disease, if treated properly, there is no recurrence after surgical removal of the mass. Respiratory and hemodynamic risks are major anesthetic concerns.
\end{abstract}

Key words: anesthesia, ascites, Meigs syndrome, ovarium tumor 


\section{Pendahuluan}

Sindrom Meigs khas dengan adanya tumor ovarium jinak yang berhubungan dengan ascites dan hidrotoraks sisi kanan. Sindrom ini kasus yang jarang dan patofisiologinya belum jelas. Diagnosis banding dengan neoplasma ovarium harus didiskusikan sebelum dilakukan tindakan pembedahan. Efusi pleura dan ascites akan hilang secaraspontandanpermanensetelah pengangkatan tumor. Anestesi untuk sindroma ini merupakan tantangan yang nyata. Masalah metabolik hemodinamik, respirasi dan hipertensi abdominal merupakan risiko anestesi utama. Pengelolaan risiko-risko ini merupakan prioritas perioperatif. ${ }^{1}$ Sindrom Meigs adalah entitas klinis langka yang ditandai dengan tumor jinak ovarium, ascites dan hidrotorak. Pengangkatan massa ovarium adalah satu-satunya pengobatan yang menentukan. Massa ovarium dengan efusi pleura dan abdominal tidak selalu merupakan keganasan lanjut. Sindrom Meigs mewakili triad efusi pleura, ascites dan adanya tumor ovarium, yang pada umumnya bersifat jinak dan terjadi bersama-sama.

Pascabedah, tanda-tanda hidrotorak dan ascites akan hilang sepenuhnya., ${ }^{2,3}$ Fibroma ovarium dengan cairan pleura dan ascites yang menghilang setelah pengangkatan tumor, diklasifikasikan sebagai sindrom Meigs yang mana tumor primernya adalah fibroma, thecoma, tumor sel granulosa, atau tumor Brenner. Dengan jenis tumor lainnya, kasus tersebut didefinisikan sebagai sindrom pseudo-Meigs. Umumnya, dapat dikenali adanya efusi pleura dan ascites, tapi ada kalanya hanya ada efusi pleura, dan disebut sebagai incomplete Meigs syndrome. ${ }^{4}$ Sindrom Meigs ditandai dengan adanya tumor padat jinak ovarium (biasanya fibroma), ascites dan hidrotorak (normalnya sisi kanan). Secara khas ascites dan hidrotoraks sembuh secara spontan dan permanen setelah pengangkatan tumor. ${ }^{5}$

Sindrom Meigs adalah kondisi langka, yang didefinisikan sebagai co-eksistensi fibroma ovarium jinak, efusi pleura dan ascites. Sedangkan sindrom pseudo-Meigs ditandai dengan adanya efusi pleura, ascites dan tumor ovarium atau panggul lainnya. Adalah Meigs dan Cass yang mengemukakan pentingnya efusi pleura dan ascites pada fibroma ovarium. Sindroma ini harus dipertimbangkan pada wanita sehat pascamenopause, yang datang dengan hidrotoraks atau ascites. Untuk kedua sindoma ini, reseksi tumor adalah satu-satuya pilihan terapi, menyebabkan resolusi akumulasi cairan. ${ }^{6}$

\section{Kasus}

\section{Anamnesa}

Wanita usia 23 tahun, datang dengan keluhan perut yang semakin membesar sejak 6 bulan sebelum masuk rumah sakit. Pasien merasa sesak. Pasien tidur dengan lebih dari 2 bantal. Riwayat penyakit diabetes mellitus, hipertensi, asma tidak ada. Tidak ada riwayat operasi dan alergi obat maupun makanan. Pasien pernah dirawat dengan keluhan serupa, dan dipasang Chest Thoracal Tube (CTT) di dada kanan. Alergi: tidak ada, Medikasi: tidak ada, penyakit yang lalu: tidak ada, makan terakhir: 6 jam sebelum operasi, keluhan: perut yang membesar.

\section{Pemeriksaan Fisik}

Keadaan umum tampak sakit berat, Kesadaran: skor Glasgow Coma Scale (GCS) 15 E4M6V5, Tinggi Badan/Berat Badan: $156 \mathrm{~cm} / \mathrm{BB} 70 \mathrm{Kg}$, Tekanan Darah 90/60 mmHg, laju nadi $122 \mathrm{x} /$ menit, reguler, laju nafas $24-26 \mathrm{kali} / \mathrm{menit}$ (posisi duduk), suhu $36,5^{\circ} \mathrm{C}, \mathrm{SpO}_{2}: 91-93 \%$

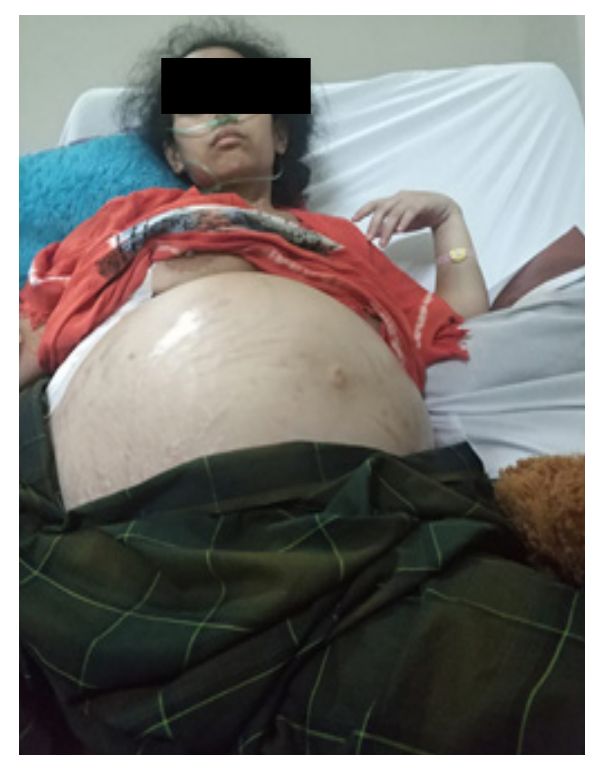


dengan udara bebas; 96-97\% dengan binasal kanul (posisi duduk). Kepala: Konjungtiva anemis (-), sklera ikterik(-/-). Mulut: Mallampati I, Buka mulut $>3$ jari. Leher: Range of Motion (ROM) baik. Toraks: Bentuk dan gerak simetris, Paru: vesicular breath sound (VBS) kanan menurun setinggi ICS 5-6, VBS kiri menurun setinggi ICS 6, rhonki -/-, wheezing -/-. Jantung: bunyi jantung S1,S2, reguler, gallop (-), murmur (-). Abdomen: cembung, seperti usia kehamilan 9 bulan, ascites $(+)$. Ekstremitas: akral hangat capillary refill $<2$ ", edema $(+/+)$, sianosis $(-)$. Diuresis: $100 \mathrm{cc} / \mathrm{jam}$, kuning jernih.

Pemeriksaan Penunjang

Pemeriksaan Lab:

\begin{tabular}{|c|c|c|c|}
\hline $\mathrm{Hb}$ & $8,2 \mathrm{~g} / \mathrm{dl}$ & $\mathrm{PT}$ & $\begin{array}{l}11,0 \\
\text { detik }\end{array}$ \\
\hline $\mathrm{Ht}$ & $27,0 \%$ & InR & 0,98 \\
\hline Leukosit & $14.150 \mathrm{~mm} 3$ & ApTT & $\begin{array}{l}30,00 \\
\text { detik }\end{array}$ \\
\hline Trombosit & $495.000 \mathrm{~mm} 3$ & SGOT & $24 \mathrm{U} / \mathrm{L}$ \\
\hline $\mathrm{Na}$ & $130 \mathrm{meq} / \mathrm{L}$ & SGPT & $9 \mathrm{U} / \mathrm{L}$ \\
\hline K & $5,3 \mathrm{mEq} / \mathrm{L}$ & Ur & $\begin{array}{l}75 \mathrm{mg} / \\
\mathrm{dl}\end{array}$ \\
\hline \multirow[t]{2}{*}{ Albumin } & $2,6 \mathrm{~g} / \mathrm{dL}$ & $\mathrm{Cr}$ & $\begin{array}{l}1,3 \mathrm{mg} / \\
\mathrm{dl}\end{array}$ \\
\hline & & GDS & $\begin{array}{l}115 \mathrm{mg} \\
/ \mathrm{dL}\end{array}$ \\
\hline
\end{tabular}

Toraks Foto

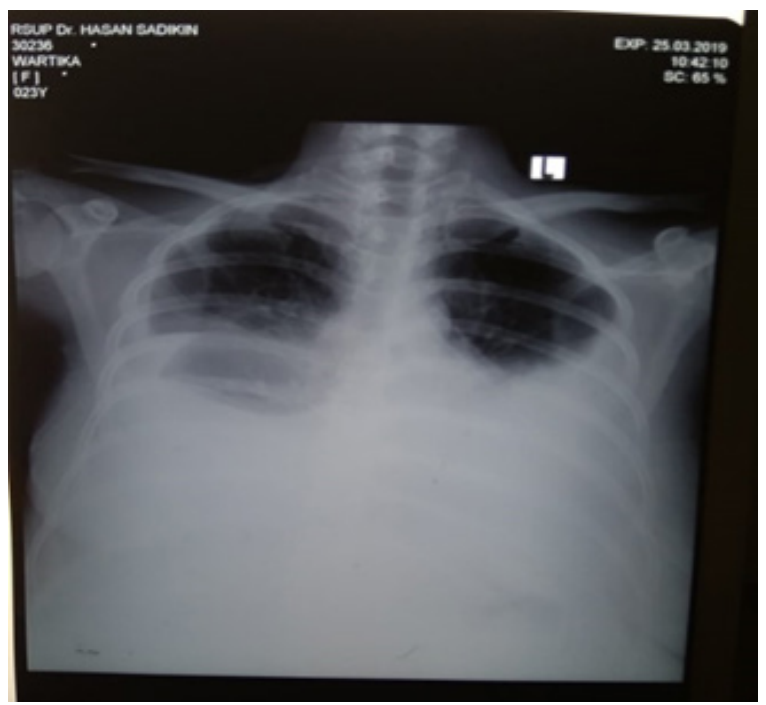

Rontgen toraks 25/03/19: efusi pleura bilateral, sedikit perbaikan, pneumotoraks kiri, chest Thoracal Tube (CTT) dengan ujung setinggi ICS 7 kanan dan ICS 4 kiri. EKG: sinus takikardi; test fungsi paru: restriktif sedang, USG abdomen: Kesan suspek tumor ganas ovarium; diagnosis: Suspek Tumor Ganas Ovarium (STGO) dengan sindroma Meigs, anemia, efusi pleura, hipoalbuminemia dan malnutrisi, disimpulkan dengan status fisik ASA III. Rencana akan dilakukan tindakan salfingoovorektomi+ Vries Coupe.

\section{Pengelolaan Anestesi}

Periode preoperatif: Puasa minimal 6 jam sebelum operasi, infus rumatan RL $140 \mathrm{cc} /$ jam, Persiapan darah dan Fresh Frozen Plasma (FFP), pasang infus dua jalur, pasang kateter urine, beri metoclopramide10 $\mathrm{mg}$, pemasangan pipa nasogastrik, pemasangan CTT oleh bedah toraks. Induksi anestesi, preoksigenasi dengan oksigen $100 \%$ dengan posisi setengah duduk diberikan selama 5 menit untuk meningkatkan cadangan oksigen pasien selama periode apneu. Pasien diposisikan setengah duduk dan sedikit miring ke kiri untuk menghindari supine hypotension syndrome atau aorto-caval compression akibat penekanan pada vena cava dan aorta abdominalis oleh massa intraabdomen yang besar. Induksi dilakukan dengan pemberian fentanyl $100 \mathrm{mcg}$ perlahan. Propofol diberikan $100 \mathrm{mg}$ secara titrasi, dengan pelumpuh otot atracurium 25 mg kemudian dilakukan laringoskopi direk dan pemasangan ETT no 7.0. Rumatan anestesi dengan isoflurane $1,2 \mathrm{vol} \%, \mathrm{O}_{2}:$ Air $=\mathrm{FiO}_{2} 50 \%$. Setting ventilator VCV f $12 \mathrm{Vt} 450$ PEEP $5 \mathrm{FiO}_{2}$ $50 \%$. Setelah intubasi pasien diposisikan supine. Saat induksi supaya tidak terjadi penurunan cardiac output dan hilangnya nadi secara mendadak, ganti cairan pengganti cairan akibat puasa. Loading dengan kristaloid atau koloid bila terjadi perdarahan selama awal operasi.

\section{Manajemen Anestesi Intraoperatif}

Monitoring ketat cairan dan perdarahan durante op. Komunikasi dengan operator saat mengangkat tumor dan aspirasi cairan ascites. Pada saat pengangkatan masa tumor, diperhatikan hemodinamik pasien, agar tidak terjadi penurunan 


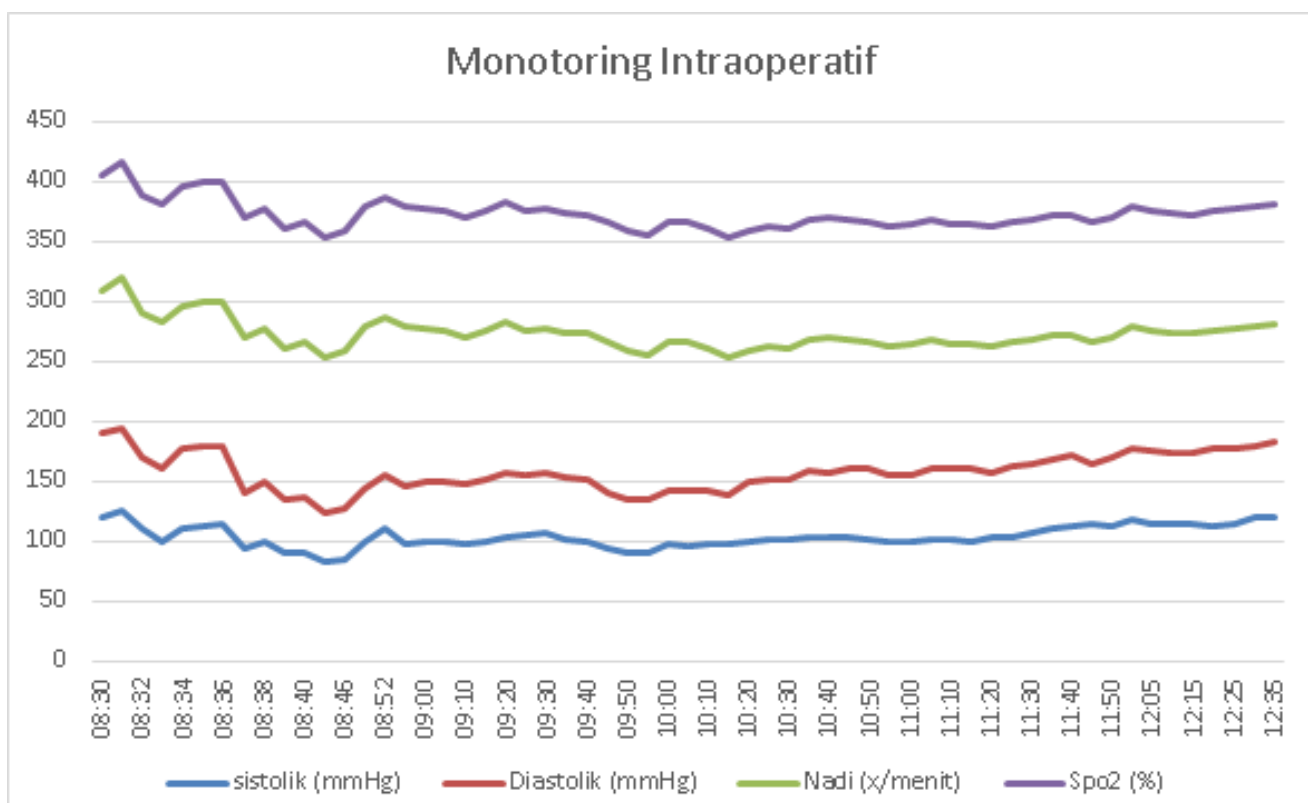

Grafik 1. Monitoring Intraoperatif

tekanan darah yang tiba-tiba dan tidak terjadi perdarahan yang hebat. Cairan yang diberikan adalah RL dan koloid gelofusin.

\section{Pengelolaan Pascabedah}

Pascabedah: skor level nyeri dinilai dengan visual analog scale (VAS) dan karena skor VAS 7-8, diberikan analgetik dengan fentanyl intravena 25 $\mathrm{mcg} / \mathrm{jam}$ dan paracetamol 4x1 gr iv. Analgetik yang cukup dan poten sangat diperlukan, karena lokasi insisi di dinding abdomen yang cukup tinggi dan hampir mendekati diafragma Penanganan pasca operatif pada pasien sindrom Meigs diharapkan setelah evakuasi massa tumor, cairan ascites dan efusi pleura dapat hilang, dan umumnya angka kejadian ascites ataupun efusi pleura akan menghilang setelah 2 minggu post operatif.

\section{Pembahasan}

Sindrom Meigs, meskipun dinamai Meigs, pertama kali dijelaskan oleh Demons dari Prancis dan Lawson Tait dari Inggris. Ini ditandai dengan adanya tumor padat ovarium yang jinak yang umumnya suatu fibroma, ascites dan hidrotoraks (normalnya pada sisi kanan). Mungkin dihubungkan dengan terjadinya pireksia dan secara khas adanya ascites, hidrotoraks dan pireksia (bila ada), sembuh secara spontan dan permanen setelah pengangkatan tumornya. Fibroma adalah tumor stroma ovarium yang paling umum dan merupakan 3-5\% dari semua neoplasma ovarium. Mereka tidak berfungsi dan jarang ganas, dan $90 \%$ terjadi setelah usia 30 tahun. Bilateralisme sekitar 15\%. Pada penampilan kasar mereka solid dan keras, sementara secara mikroskopis ada bundles of bland spindle cells dengan pemanjangan inti sel, berpotongan dengan bundle jaringan fibrosa kolagen. Ascites terjadi pada $10-15 \%$ kasus ketika ukuran tumor lebih dari $10 \mathrm{~cm}$. Sindrom Meigs klasik memiliki insiden $1 \%$ dari semua fibroma ovarium. ${ }^{5}$ Sindrom Meigs dapat menyebabkan komplikasi pernafasan dan hemodinamik yang parah selama anestesi yang disebabkan oleh massa yang besar dalam ruangan peritoneal, ascites dan efusi pleura yang banyak. Teori untuk menjelaskan patofisiologi dari efusi peritoneal dan pleura telah dibuat. Kompresi mekanis atau torsi parsial fibroma atau tumor jinak ovarium padat lainnya mengarah pada produksi ascites oleh limfatik yang dilepaskan dari permukaan tumor. Ada eksudasi dari peritoneum karena iritasi mekanis oleh tumor. Ada cedera atau nekrosis dari pembentukan kista dalam tumor. Baru-baru ini telah disarankan 
kemungkinan sekresi aktif oleh growth factor tumor yang memediasi hiperpermeabilitas dalam ovarium atau pembuluh darah peritoneal. Dalam mekanisme produksi hidrotoraks, ascites bermigrasi ke rongga toraks kanan melalui defek kongenital atau kelebihan cairan limfe, yang lebih umum terjadi pada sisi kanan. Oleh karena itu, kejadian hidrotorak di sisi kanan lebih tinggi. ${ }^{1}$

Pasien dengan sindrom Meigs mengeluh gejala perut dan pernafasan. Peningkatan tekanan intraperitoneal, yang disebabkan isi dalam rongga peritoneum, dapat memiliki efek fisiologis yang merugikan, seperti penurunan curah jantung, kelainan ventilasi-perfusi dengan hipoksia dan hiperkapnia, penurunan aliran perfusi renal dan filtrasi glomerulus dengan penurunan urine output, peningkatan tekanan intrakranial, dan gangguan perfusi liver dan gastrointestinal. Akan tetapi, tantangan utama bagi spesialis anestesi adalah adanya hipertensi abdominal dan kemungkinan terjadinya abdominal compartment syndrome. Hipertensi intra-abdominal didefinisikan oleh peningkatan patologis yang berkelanjutan atau berulang tekanan intraabdomen $\geq 12 \mathrm{mmHg}$.

Evolusi ke abdominal compartment syndrome, yang didefinisikan sebagai tekanan intraabdomen lebih dari $20 \mathrm{mmHg}$ yang dikaitkan dengan kegagalan organ baru. Berbagai kasus abdominal compartment syndrome yang memberatkan sindrom Meigs telah dilaporkan. Terapi untuk sindroma ini berdasarkan pada vascular filling, sedasi, analgesia, posisi reverse Trendelenberg, neuromuscular blockade dan dekompresi bedah. Indikasi untuk dekompresi ini masih kontroversial. Dalam persiapan prabedah, pengukuran tekanan intraabdomen dilakukan untuk memantau hipertensi intraabdomen 1 Banyak pasien dengan sindrom Meigs dalam keadaan malnutrisi, anemia dan ketidak seimbangan elektrolit yang memerlukan koreksi. Untuk mengatasi masalah ini, managemen anestesi dimulai dari evaluasi preoperatif yang baik dan menilai pentingnya dampak pernafasan, hemodinamik dan metabolisme. Efusi pleura dapat menimbulkan chest pain. Sesak nafas; jumlah cairan dievaluasi dengan X-ray. Ekstrim, hipoksik distress pernafasan memerlukan aspirasi transudat pleural dan abdominal untuk mengembalikan fungsi dan fisiologi pernafasan ke nilai mendekati normal. Aspirasi harus diulang jika perlu: aspirasi akhir dilakukan pada hari operasi.

Beberapa faktor berkontribusi pada desaturasi, abdominal compartementsyndrome terkait dengan sindrom Meigs dan pembentukan atelektasis, terkait dengan induksi anestesi dan terutama paralisis oleh pelumpuh otot. Untuk memperbaiki masalah desaturasi intraoperatif ini, dilakukan beberapa prosedur, tetapi manuver rekrutmen alveolar merupakan prosedur yang paling efektif. Satu-satunya keterbatasan maneuver ini adalah konsekuensi hemodinamik. Penurunan tekanan darah dikoreksi dengan ekspansi volume dan vasokonstriktor. ${ }^{1}$ Anemia preoperatif umum terjadi pada sindrom Meigs dan dikaitkan dengan kemungkinan peningkatan transfusi darah dan peningkatan morbiditas perioperatif. Koreksi dengan transfusi sel darah merah atau whole blood, mungkin diperlukan. Gangguan elektrolit lainnya harus diperbaiki sebelum operasi. Harus diperhatikan tentang premedikasi. Obat berbasis opioid atau benzodiazepine harus dihindari karena risiko depresi pernafasan praoperasi, hipoventilasi dan hipoksemia.

Karena risiko regurgitasi sebagai konsekuensi peningkatan tekanan intraabdominal dan terbatasnya gerakan diaphragma, tehnik anestesi adalah crash induction dengan Sellick's maneuver setelah dilakukan preoksigenasi dalam posisi proclive (kepala lebih tinggi dari kaki). Tekanan toraks umumnya tinggi, masalah ini dapat diselesaikan dengan menggunakan posisi proclive, laparotomi cepat untuk mengeluarkan ascites. Pascabedah dilakukan pemeriksaan X-ray lagi untuk melihat sisa efusi pleura. Jarang diperlukan untuk melakukan aspirasi dada pascabedah, akan tetapi, ada kemungkinan masih ada hipoksia pada saat pemulihan. ${ }^{1}$ Eksisi tumor besar dikaitkan dengan risiko perdarahan karena ukuran tumor, dan hubungan anatominya. Ini dapat menimbulkan perubahan hemodinamik introperatif dan diperburuk dengan tidak adekuatnya venous return disebabkan tekanan abdominal. Hal ini memerlukan pemantauan intraoperatif yang adekuat, melakukan pemeriksaan laboratorium 
untuk transfusi, mengantisipasi kehilangan darah dengan mengoptimalkan volume darah dan ambang transfusi. Manajemen nyeri pascabedah dengan analgesi multimodal dan opioid intravena. ${ }^{1}$ Sindrom Meigs didefinisikan sebagai trias tumor ovarium jinak dengan ascites dan efusi pleura yang sembuh setelah reseksi tumor. Fibroma ovarium merupakan mayoritas tumor jinak yang terlihat pada sindrom Meigs. Sindrom Meigs adalah diagnosis eksklusi, hanya setelah karsinoma ovarium disingkirkan. ${ }^{7}$ Tanda dan Gejala Sindrom Meigs: Keluhan utama tidak jelas dan umumnya bermanifestasi dari waktu ke waktu yaitu kelelahan, sesak nafas, peningkatan lingkar perut, penambahan/penurunan berat badan, batuk tidak produktif, kembung, amenorrhoe pada wanita premenopause, ketidakberaturan menstruasi. ${ }^{7}$

Perawatan dan Penatalaksanaan: Perawatan medis pasien dengan sindrom Meigs dimaksudkan untuk meredakan gejala ascites dan efusi pleura melalui parasentesis terapeutik dan torakosintesis. Perawatan bedah: resolusi setelah reseksi tumor telah banyak didokumentasikan. Laparatomi eksplorasi dengan surgical staging adalah pengobatan pilihan. ${ }^{7}$ Patofisiologi sindrom Meigs: Ascites terjadi pada 10-15\% kasus, dan hidrotoraks hanya ditemukan pada $1 \%$ kasus. Patofisiologi ascites pada sindrom Meigs bersifat spekulatif. Meigs menyarankan bahwa iritasi pada permukaan peritoneum oleh tumor ovarium padat yang keras dapat merangsang produksi cairan peritoneum. Etiologi efusi pleura belum jelas. Teori bahwa cairan ascites ditransfer melalui saluran limfatik transdiaphragma. ${ }^{7}$

Etiologi ascites dijelaskan dengan mekanisme sebagai berikut. ${ }^{5}$ :

a). Torsi partial dari pedikel vaskuler ovarium yang menyebabkan pembengkakan vena dan transudasi cairan serosa dari tumor, yang masuk ke ruang pleura melalui limfatik diaphragma atau melalui defek pada diaphragma yang sering terjadi pada sisi kanan.

b) Eksudasi dari peritoneum disebabkan karena iritasi mekanis oleh tumor yang keras dan besar.

c) Degenerasi fibroma

d) Perubahan vena kapsular dari fibroma

e) Sekresi aktif dari tumor.
Satu laporan kasus, seorang wanita, 51 tahun, datang dengan massa di abdomen, ascites dan efusi pleura kiri. CA 125 serumnya adalah $820 \mathrm{U} /$ $\mathrm{ml}$. Eksplorasi bedah mengungkapkan leiomioma rahim jinak tanpa sitologi ganas di ascites. Pasca operasi, efusi pleura berkurang secara dramatis dan CA125 menurun ke kisaran normal setelah 4 bulan pasca operasi. Ini adalah kasus sindrom pseudo-Meigs yang sangat jarang yang disebabkan oleh leiomioma uteri. ${ }^{8}$

Leiomioma uterin jarang menyebabkan sindrom pseudo-Meigs dengan peningkatan kadar cancer antigen (CA) 125 serum. Hubungan langsung yang diduga antara banyaknya cairan intratumoral dan adanya ascites tampaknya dibenarkan. Peningkatan kadar CA 125 kemungkinan besar disebabkan oleh iritasi mekanis peritoneum dari leiomioma yang besar atau dari volume ascites yang besar. Setelah mengumpulkan volume dan tekanan yang cukup, ascites menemukan jalan diaphragma melalui celah antar sel dan lubang diaphragma, serta melalui area bilateral kecil dimana jaringan otot diaphragma digantikan oleh jaringan areolar, mengakibatkan adanya cairan pleura. ${ }^{9} 10$ Pada kasus ini evaluasi pre anestesi dilakukan penjelasan tentang penyakit. Pada pasien yang akan menjalani operasi didaerah abdominal ada beberapa hal yang menjadi perhatian khusus diantaranya status hidrasi pasien, perubahan hematologi dan metabolik, lama operasi dan semua pasien yang akan menjalani operasi daerah perut dalam kondisi emergensi harus dianggap lambung penuh. Sesak nafas bisa karena efusi pleura yang cukup banyak dan perut yang membesar sehingga mendorong diagfragma. Biasanya pasien ditemukan dengan keadaan duduk atau setengah duduk. Pasien ini ditemukan dalam kondisi setengah duduk dan pasien bisa tidur dengan satu bantal tetapi akan lebih nyaman bila memakai dua bantal. Pasien sering ditemukan dalam keadaan dehidrasi oleh karena asupan yang kurang. Pemasangan jalur intravena untuk memastikan hidrasi pasien dan sebagai ganti input cairan sehingga pasien tidak dehidrasi. Perut yang besar dan distensi bukan hanya akibat dari masa tumor, melainkan dapat disebabkan cairan ascites. Pengurangan cairan ascites dapat dilakukan pre operatif dengan 
abdominal parasintesis. Abdomen yang besar dan distensi merupakan pertimbangan serius ketika akan dilakukan tindakan anestesi. Pemasangan NGT untuk mencegah regurgitasi dan resiko aspirasi. Dilakukan punksi pleura dan dilakukan pemberian metoclopramide $10 \mathrm{mg}$ intravena untuk mempercepat pengosongan lambung. Untuk menjaga kemungkinan terjadi perdarahan selama operasi, maka dilakukan persiapan persediaaan darah.

\section{Simpulan}

Sebagai simpulan pada laporan kasus ini adalah sindroma Meigs adalah penyakit jinak, jika, diterapi dengan benar, tidak ada kekambuhan setelah operasi pengangkatan massa. Risiko pernafasan dan hemodinamik merupakan masalah anestesi utama. Managemen perioperatif yang optimal dari risiko-risiko ini mempertahankan prognosis yang baik dari sindroma ini.

\section{Daftar Pustaka}

1. Fjouji S, Bensghir M, Haimeur C, Azendour $\mathrm{H}$. Anesthetic consideration in DemonMeigs' syndrome: a case report. Journal of Medical Case Report 2014;8:320

2. Liao Q, Hu S. Meigs' Syndrome and PseudoMeigs' syndrome: report of four cases and literature review. Journal of Cancer Therapy 2015;6(4):293-98

3. Santangelo $M$, Battaglia $M$, Vescio $G$, Sammarco G, Gallelli G, Vetere A, et al. Meigs' syndrome: Its clinical picture and treatment. Ann Ital Chir 2000 JanFeb;71(1):115-9.
4. Tsukao H, Ueda T, Fujii Y, Sakai T, Yamaguchi T, Nakaya J, Kojima T. Incomplete pseudoMeigs' syndrome cause by endometrial ovarian cyst: a case report. Respiratory Medicine Case Report 2021;33:101387

5. Chaitali DR, Pratim SP, Sarmishtha C, Shanti S. Meigs syndrome - A case report. J Obstet Gynecol India 2006;56(5) : 451-53

6. Kallarackal D, Singh D. Pseudo-Meigs syndrome: A case report. Int J Case Rep Images 2017;8(5):331-34.

7. Lessnau KD, Anariba DEI, Lanza J, Ali MO, Kanaparthi LK, Chavda R, Talavera F, Randall LM. Meigs syndrome. Drug \& Disease Obstetrics \& Gynecology. Medscape 2021

8. Migishima F, Jobo T, Hata H, Sato R, Ikeda Y, Arai M, Kuramoto H. Uterine leiomyoma causing massive ascites and left pleural effusion with elevated CA 125: A case report. J Obstet Gynaecol Res 2000 Aug;26(4):2837

9. Amant F, Gabriel C, Timmerman D, Vergote I. Pseudo-Meigs' syndrome caused by a hydropic degenerating uterine leiomyoma with elevated CA 125. Gynecol Oncol 2001 Oct;83(1):153-7.

10. Long CY, Chen YH, Chen SC, Lee JN, Su $\mathrm{JH}$, Hsu SC. Pseudo-Meigs syndrome and elevated levels of tumor markers associated with benign ovarian tumors--two case reports. Kaohsiung J Med Sci 2001 Nov;17(11):5825 . 